\title{
INSTITUTIONALIZATION OF FOREIGN POLICY THINK TANKS IN ITALY AND IN THE UK: AN EXPLANATORY FRAMEWORK
}

Anna Longhini

Scuola Normale Superiore, Florence

Abstract: This article explores the phenomenon of foreign policy think tanks in Europe in a comparative perspective and offers a framework of analysis for this topic. Assuming that think tanks were largely imported from the US after World Wars I and II, the article argues that European think tanks have been influenced by the different national political contexts in which they have undergone a process of institutionalization. First, the article hypothesizes that such contexts have contributed to determining different incentives for cooperation between think tanks and national policymakers. Such cooperation is based on the willingness of policymakers to turn to think tanks for expertise, advice or validation of policy decisions. Secondly, different political contexts are expected to influence the strategies of action that think tanks have developed towards policymakers and their audience. In this respect, the article identifies three strategies: the generalist, the advocate and the lobbyist. Empirically, the article is based on a survey of eleven organizations conducted in two countries, Italy and the United Kingdom, in 2013-14. Given that very few data are available on this type of organization their activities, funding, policy audience and goals are investigated. These indicators are used to investigate the main commonalities and differences between the two cases and to compare them with the hypotheses. The results first show that there is comparatively more funding available for think tanks in the UK system than in the Italian one. Secondly, there is apparently more willingness from policymakers to turn to think tanks for expertise in the former case, considering that the UK think tanks hold a higher number of closed-door events and parliamentary hearings. On the contrary, where policymakers tend, instead, to more scarcely rely on external expertise - as it seems more evident in the Italian case the core audience of think tanks tends to shift to other, more accessible targets (the public opinion, the academia or even businesses). The case study makes it more evident how advocacy becomes a far less important activity for an Italian think tank than a UK one.

Key words: institutionalization, think tanks, political contexts, actors' cooperation, expertise, foreign policy, Italy, United Kingdom, survey

ANNA LONGHINI - Institute of Humanities and Social Sciences, Scuola Normale Superiore, Italy•anna.longhini@sns.it

Central European Journal of Public Policy Vol. 9 - № 2 - December 2015 - pp 96-121

ISSN 1802-4866

(c) 2015 Anna Longhini

Licensed under Creative Commons Attribution 3.0

\section{INTRODUCTION}

This article explores the phenomenon of think tanks involved in foreign policy and international affairs in Europe using a comparative perspective ${ }^{1}$. It assumes that this type of actor - the foreign policy think tank - was largely imported from the United States and, empirically, it looks at two cases: Italy and the UK.

After the First and Second World Wars, a number of research organizations with an international focus were established in Europe. This was largely the result of influence by, and in some cases direct coordination with, US counterparts $^{2}$. Representing a typical US non-state actor ${ }^{3}$, the very concept of a think

1 According to the Oxford English Dictionary, 'foreign policy' is the strategy of a government in dealing with other nations. Roughly compared to domestic politics, foreign policy in Western democracies is not a very conflictual policy, because it rarely causes collective political strug gle. Indeed, when it actually does, this may cause revolutions or conflicts (Tilly \& Tarrow, 2007). There are different competing views of who influences the decisions taken by government officials relative to foreign policy issues (Jacobs \& Page, 2005, pp. 107-108). Think tanks and experts are expected to have a role in this process, but this role is debated or uncertain (Abelson, 2013). In this article, think tanks dealing with foreign policy in Western Europe are understood as those government agend

2 For instance, in 1919 British and American delegates to the Paris Peace Conference conceived the idea of an Anglo-American Institute of Foreign Affairs to study international problems with a view to preventing future wars. The British Institute of International Affairs was founded separately in London in July 1920, while the American delegates developed the Council on Foreign Relations in New York as a sister institute. See more at: http://www.chathamhouse.org/about/ history\#sthash.ikVufTcO.dpuf (accessed 27 January 2015).

3 The emergence of think tanks in the U.S. is connected to need of the country to cope with global challenges and threats. See Abelson (2006, pp. 74-75) and Abelson (2002). Also, the etymology and the evolution of the concept of 'think tank' itself are connected to foreign policy and the military world. According to the Oxford English Dictionary, the word 'think tank' was used in 
tank has rarely been an object of analysis in Europe. Most literature on this issue is American and it examines American think tanks ${ }^{4}$. This article aims to fill a part of this gap by investigating the relevance of these actors both theoretically and empirically.

The article is structured as follows. The first part offers a theoretical framework to explain the process of institutionalization that foreign pol icy think tanks have undergone in the different European political contexts in which they spread ${ }^{5}$. After suggesting a definition of a 'think tank', two main hypotheses are put forward. First, we hypothesize that these contexts determine the incentives or disincentives associated with cooperation ${ }^{6}$ between think tanks and national policymakers. This cooperation rests on the willingness of policymakers to turn to think tanks for expertise (in the article expertise is used as a synonym of 'usable knowledge ${ }^{77}$ ), advice, or simply validation of policy decisions ${ }^{8}$. In other words, it is not sufficient for think tanks to seek acces to officials if the context does not favour such cooperation. Second, we hypothesize that these contexts influence the strategies of action that think tanks, as organizations, have developed with respect to policymakers and their audience. Following this, three types of strategies that a foreign policy think tank may pursue relative to the way it engages with policymakers are proposed and explained: the generalist, the advocate and the lobbyist. In the second part of the article, the methods and cases of an exploratory survey of eleven organiza-

common American English as a synonym of 'brain', but at the end of the Second World War it became a way to describe a safe place where experts, both civilian and military, could think of and plan international strategies and operations. During the 50's and the 60's the term remained anchored to the military field: "[...] 'think tank[s]' - as reported on the 'Business Week' magazine in 1963 - do analytical work for the armed forces, such as the Air Force's RAND Corp., the Navy's Operations Evaluation Group, the Army's Research Analysis Group, the Defense Dept.'s Institute for Defense Analysis."

4 See, for instance: Abelson (2013); Medvetz (2012); Wiarda (2010); Abelson (2006); Diletti (2009) Jacobs \& Page (2005); Boucher (2004); Higgot \& Stone (1994); Weaver (1989).

5 William Wallace has suggested that think tanks operate within distinctive national environments, and are shaped by the need to adapt to that environment. See Wallace $(1994$, p. 145).

6 The idea of cooperation among political actors is derived from a study by Kriesi, Adam \& Jochun on power structures and policy networks in Europe. With respect to actors' interactions thes scholars suggest that a different "degree of co-operation among actors and actor coalitions" (2006, p. 342) exists in each of the three main forms: competition, bargaining and co-operation.

7 Usable knowledge is a kind of knowledge that differs from more academic knowledge, especially in the way in which it is proposed to its audience. More complex concepts, for instance, can be simplified and proposed to decision makers in short documents. See Hill \& Beshoff (1994). See also: Lindblom \& Cohen (1979); Nowotny (1990).

8 As Bertelli and Wenger suggested: "Think tanks can provide legislators with that credibility through research that supports their ideological policy preference." See Bertelli and Wenger (2009, p. 228). tions in Italy and Britain are presented and the main results are discussed. Specifically, the following indicators have emerged from the field work: activities, funding, policy audience and goals. Discussing these indicators, the rest of the article explores the communalities and differences between the two cases in order to compare the empirical part with the hypothesis made in the first part.

\section{AN EXPLANATORY FRAMEWORK}

Think tanks are a challenging topic for scholars, not only because they can be studied through the perspective of different subfields of political science from public policy to international relations ${ }^{9}$ to political communication (Sanders, 2008), but also methodologically. First, the word 'think tank' has become a global label to identify different types of organizations ${ }^{10}$. That is why there is not a unique accepted definition of it. For instance, the Dictionary of British Politics suggests that a think tank is: "a research and development organisation which brings together academics, technocrats and politicians who wish to advance a specific policy or ideological agenda." Scholars have extensively tried to define these organizations, but the boundaries between a think tank and other organizations are still weak: "along with interest groups, trade associations, human rights organizations, advocacy networks and a handful of other bodies, think tanks rely on their expertise and knowledge to influence public opinion and public policy. What has distinguished think tanks in the past from the other organizations mentioned above is their reputation for being objective, scientific and non-partisan. (Abelson, 2007, p. 551)" Think tanks, though, may also be partisan and we cannot distinguish them from other organizations just based on partisanship. Most Washington think tanks are politicized and partisan (Gilroy, 2012).

In this article, for the sake of the argument, think tanks are understood as organizations that 1) rely on expertise and 2) engage with their external environment not just in general terms, but specifically with a view to cooperating with policymakers. On the one hand, that means that think tanks can conduct research by producing or aggregating a type of knowledge that is usually con-

9 Whilst international relations theory is dominated by state-centric literature, a public policy approach is keener to consider a pluralist actor model, rather than a unitary one. In other words, in a public policy approach there is not one single central decision maker ("the state"), but different domestic as well as transnational actors arep sue can be found in Putnam (1988) and in Hill (1994).

10 This fact has been favoured by an international ranking of think tanks published by James McGann since 2007. See: http://gotothinktank.com/ (accessed 27 January 2015). 
sidered 'usable'. Indeed, most of their outputs consist of what is called 'policy-oriented research' and policymakers are supposed to be the final users. However, think tanks may also be engaged in 'academic research', which is generally less appealing to decision makers, but can offer robust evidence and in crease the reputation of think tanks. On the other hand, whether or not think tanks are partisan (advance an ideological agenda), they should address their research to a wider or more restricted policy audience, which must include policymakers. Therefore, for the purposes of this research, think tanks are understood as organizations seeking, more actively or more passively, cooperation with policymakers - which might be formal (contracts for research, for example) or informal - at least by informing their debate. In particular, this article relies on two hypotheses.

HP 1: As foreign policy think tanks were largely external actors to most European countries (a type of institution imported from the US) and have progressively become institutionalized within these countries, then different national political contexts may set incentives or disincentives to the cooperation between think tanks (as concrete existing organizations) and policymakers. In this first hypothesis it is worth underlining that there is a double reference to the term think tank: in the first part of the phrase the think tank is just a type of institution typical of the United States, whose model was imported in Europe; the think tanks in the second part are, instead, those concrete organizations which have grown in different European contexts, modelled from the original institutional design. Cooperation, then, depends not only on the supply of expertise from think tanks but also on policymakers' demand for it. In other words, simply seeking access is not enough for think tanks if the context does not favour their cooperation with policymakers. Specifically, this cooperation may be based on an exchange of usable knowledge, which can be considered in terms of advice, used to validate policy decisions or, at best, built on to change the policy configurations of an issue ${ }^{11}$. When cooperation is intensive and continuous, it is likely that the capacity of think tanks to attract funding, either from business or from the state, increases, as would the institutionalization of expert participation in the policy debate and policy formulation.

Secondly, the different levels of cooperation between think tanks and policymakers also affect the strategies of action of think tanks. Thus, the

11 For instance, following the January 7, 2015, attack against the Charlie Hebdo newspaper in Paris, the state of anti-terrorism laws has been put under revision in Italy, in the UK and in Canada. Experts have had a window of opportunity to contribute this issue. On the new law proposal in Italy, see: $\quad$ http://www reuters.com/article/2015/02/10/us-security-italy-idUSKBNOLE2WH20150210. see: $\quad$ http./Www.reuters.com/article/2015/02/10/Us security terrorismo-nuove-misure-nuove-minacce-12545 (accessed 13 February 2015). second hypothesis is formulated as follows. HP2: If different types of cooperation between think tanks and policymakers exist in different contexts (a high level of cooperation has always been taken for granted in the case of US think tanks), then these diversities are expected to induce the pursuit of different strategies of action for think tanks relative to their policy audience (particularly officials). The empirical analysis has identified the following actors as the audience of foreign policy think tanks: public opinion, academia, media, businesses, military industry, diplomats, officials, politicians, other think tanks, and the third sector. Of those, though, officials are thought to be the most important targets for a think tank. The question 'do think tanks influence officials?' derives from this assumption. Nonetheless, the causal mechanism that underlies this argument may change when the political context is not taken for granted. In other words, a think tank may engage more actively or more passively with policymakers because of the context. There are different actors that can take part on the demand side of a hypothetical 'market of expertise' and constitute the policy audience of a think tank. Among those, policymakers are not always the primary target of any think tank. Therefore, when this is not the case, think tanks have a more passive engagement with policymakers (possibly due to their low demand for expertise and/or contribution to funding the sector), and their preference is to diversify their audience. On the contrary, a think tank may prefer to engage with policymakers more actively (for instance, organize dedicated events more frequently where they are invited as principal participants, address specific products only to them, etc.)

In more general terms, there are different strategies that a think tank can pursue. This article identifies three: the generalist, the advocate and the lobbyist. These strategies are based on a typology that follows and is explained in the next pages.

Table 1 Typology of the strategies of foreign policy think tanks

Audience Restricted Broad

Type of engagement

with policymakers

\begin{tabular}{lll}
\hline Active & The lobbyist & The advocate \\
\hline Passive & Irrelevant & The generalist \\
\hline
\end{tabular}

One dimension of the table represents the type of engagement a think tank can have with policy makers, while the other stands for the type of audience 
it reaches, which can be restricted or broad ${ }^{12}$. In this model, if the audience is restricted but there is an active engagement with policymakers, the corresponding ideal-type strategy on the top left-hand side of the Table 1 is called 'the lobbyist'. On the top right-hand side, 'the advocate' is a type of strategy which involves both active engagement with policymakers and engagement with a broad audience. Engagement with policymakers might, however, also be passive. There are different reasons why this happens. The hypotheses that are made in this respect are specific to the context in which think tanks operate and include: lack of funding (private and public donors both have a mainly domestic origin); unattractiveness of activities carried out (they might not be specifically suited to policymakers); lack of interest from policymakers and legislators (measured in numbers of parliamentary hearings every year); and goals of the organization. The assumption is made that if the engagement with both policymakers and other policy actors is weak, the organization analysed is not relevant enough to claim to be a think tank. However, if the engagement with policymakers is passive but the audience is broad the think tank falls under the 'generalist' category.

None of these types has any negative connotation, although most think tanks would not like to be in the 'lobbyist' or 'generalist' category. It should be kept in mind that most think tanks interviewed would agree that policy influence "is connected to setting the agenda, and it is not about manipulating an output. Influence is when you are able to set the priority of an issue over others and to push it onto the government agenda." ${ }^{13}$ Further specification of each of the strategies presented in this article follows

It is important to clarify that the term 'strategy' is used in this context as a way through which a think tank, actively or passively, engages with their external environment, and specifically with policymakers. The strategy of a think tank identified here should not be confused with the types of think tanks identified in the literature ${ }^{14}$. As mentioned above, three strategies have been hypothesized in the model proposed: the generalist, the advocate and the lob-

12 Empirically, the method used to identify the audience of a think tank was through the question on what its research targets were. Research targets may range from public opinion to the media, from businesses to diplomacy, from the military to other think tanks and to officials and politicians in general.

13 Anonymous interview, Rome, September 2014

14 All classifications of think tanks originate from Weaver's (1989) three types: universities without students, government contractors and advocacy think tanks. The types identified by Weaver do not particularly help in discriminating between European think tanks. For instance, a high number of them would qualify as both 'universities without students' (in the sense of being 'rather academic) and 'goveryment contractors', but not in the 'advocay' (partisan) category. However, in the classification of Weaver the academic type would be primarily financed through byist. In general terms, the generalist is quite passive when engaging with policymakers, while the other two categories imply a more active commitment. Also, it is expected that each of the think tanks included in the sample in Italy and the UK follows one of these strategies. They are investigated in the next pages, while a description of each strategy follows.

The term 'lobbyist' relates to the term 'to lobby', which means to press somebody to do something. A lobbyist is an individual or an organization that applies pressure to the legislative in order to obtain changes in the laws being adopted. The lobbyist is a professional who acts within the political environment, yet remains external to the government. In the context of this paper, 'the lobbyist' refers to a strategy of a think tank with the following features. The think tank only organizes events behind closed doors. These events are directed towards policymakers or towards a small audience: specifically, in most cases, politics and business representatives meet with experts. The 'lobbyist' usually succeeds in engaging with officials by seeking and gaining access to them, by often participating in parliamentary hearings, or by being able to convene with them regularly at their office. A lobbyist strategy applies no only when the main prerogative of the think tank is that of continually seeking access to decision makers and to the decision-making process as a whole but also when such access is constantly achieved. In contrast to the other two types of strategies that will be investigated, the lobbyist seldom seeks day-today visibility.

An advocate think tank argues or acts in order to promote policies toward well-defined target audiences. It might pursue its goals through attempting to reach and influence different audiences, using different tools. Policymakers are one of the audiences of this active strategy. Similarly to advocacy organizations, which strongly support a cause, an advocacy think tank supports defined policy ideas. What makes the term 'advocacy' problematic, used together with that of 'think tank', is that policy ideas in foreign policy are not always so explicit, whilst a concrete cause is generally more evident. In contrast to 'lobbyist' think tanks, advocacy think tanks are accessible to interested public opinion: they hold both closed- and open-door events, which are not directed exclusively towards policymakers. The advocate seeks access to or is able to convene highlevel officials, both at the national and the international level.

The generalist also organizes closed- and open-door events, which are not addressed to policymakers only. The goals of think tanks in this category are to maintain their reputation and inform the debate through the production

foundations, corporations or individuals. This feature is not really applicable to those think tanks in Europe that can be deemed to have a much more academic configuration. 
of policy research. They may decide to seek access to policymakers, but these efforts are less systematic than is the case with the other two categories described. This might also be caused by the fact that they are not always able to convene with high-level officials. Nonetheless, the generalist consciously and extensively engages with its external environment, addressing a broader policy audience. As a consequence, its strategy is less defined, precise and targeted than the other two described above. Especially, as many as those activities are unable to generate sufficient funds, the generalist think tank fails to be more ambitious in its goals. It is undeniable, though, that the generalists are more likely to reach the attention of policymakers when a 'window of opportunity' opens in their favour. For instance, this may happen when a conflict erupts in a geographical area where their researchers have developed specific competences or covered the phenomenon in their research agenda. Global crises and security threats usually stimulate the demand for expertise from the political world.

\section{METHODS AND CASES}

How can the engagement of a think tank with policymakers and other audiences be successfully measured? In order to conceptualize a topic it is necessary to translate "the words that surround it in 'real-existing' societies or polities into variables" (Schmitter, 2008, p. 268). However, the relationships that this article hypothesizes (e.g., cooperation between think tanks and policymakers) are neither direct nor linear. This means that we do not expect a quantitative result.

This work is mainly qualitative: there are "few observations (small N), and hence analysed with words rather than numbers" (Gerring, 2006, p. 216). Methodologically, this article follows a case study approach: it analyses a "small number of units (the cases) for the purpose of understanding a larger class of similar units (a population of cases)" (Gerring, 2007, p. 37). The small number of units in this research is represented by the cases of Britain and Italy, and the larger class or population of similar units by Europe. Rephrasing Gerring the aim of the article is to understand the phenomenon of foreign policy think tanks in the European population of cases through the study of a limited number of cases. In addition to this, the empirical part of this article is exploratory - it follows the logic of discovery (Schmitter, 2008, p. 271) - as few data exist on the organizations surveyed; and such data are also rarely publicly accessible. Indeed, the think tank sector is not subject to any specific regulation in either of the countries of analysis ${ }^{15}$, and therefore, in this research, field work is used to fill this gap. Specifically, the study is based on the following indicators: activities, funding, policy audience, overall goals, and parliamentary hearings. They are explained in the Table 2.
15 Most think tanks take the legal form of not-for-profit organizations. In Italy these organizations are not always committed to transparency, nor are they obliged to publish their annual statement. In Britain, those think tanks that decide to register as a charity are obliged to be more transparent. Their financial data are available on the website of the UK Charity Commission. See: https://www.gov.uk/government/organisations/charity-commission (accessed 14 January 2015). A European Union Transparency Register has been established in an effort to fulfil the need of A Eur transper even if Section IV of the Register is reserved specifically for them. See: http://ec.europa.eu/trans-
parencyregister/ (accessed 14 January 2015). 
Table 2 Indicators identified of the relations between think tanks and their external environment

\begin{tabular}{|c|c|c|}
\hline Indicators & Observed range of variation & Observed answers \\
\hline Activities & $\begin{array}{l}\text { From more traditional academic } \\
\text { research to more active } \\
\text { involvement in activities of } \\
\text { unofficial diplomacy }\end{array}$ & $\begin{array}{l}\text { - Research/publication } \\
\text { - Events and communication } \\
\text { - Education } \\
\text { - Track II16/unofficial diplomacy }\end{array}$ \\
\hline Funding & $\begin{array}{l}\text { Annual budgets in the examined } \\
\text { sample of think tanks vary from } \\
\text { below } 1 \mathrm{M} \text { euros to } 16.5 \mathrm{M} \text { euros }\end{array}$ & $\begin{array}{l}\text { - Below } 1 \mathrm{M} \text { euros } \\
-1-4 \mathrm{M} \text { euros } \\
-4.5-5.5 \mathrm{M} \text { euros } \\
\text { - More than } 10 \mathrm{M} \text { euros }\end{array}$ \\
\hline $\begin{array}{l}\text { Policy } \\
\text { audience - } \\
\text { type of events }\end{array}$ & $\begin{array}{l}\text { Events may be open, invitation- } \\
\text { only or strictly closed to the general } \\
\text { public }\end{array}$ & $\begin{array}{l}\text { - Closed-door/invitation-only events } \\
\text { (CD) } \\
\text { - Open-door event (OD) }\end{array}$ \\
\hline $\begin{array}{l}\text { Policy } \\
\text { audience - } \\
\text { targets }\end{array}$ & $\begin{array}{l}\text { Different types of people/ } \\
\text { organizations the think tank aims to } \\
\text { communicate with. It may involve a } \\
\text { broad audience or a restricted one }\end{array}$ & $\begin{array}{l}\text { - Officials (government and admin.) } \\
\text { - Business } \\
\text { - Politics } \\
\text { - Third sector } \\
\text { - Journalists/media } \\
\text { - Diplomats } \\
\text { - Academia } \\
\text { - Public opinion } \\
\text { - Other think tanks }\end{array}$ \\
\hline
\end{tabular}

16 There are different definitions and understandings of track two diplomacy, and they are even more blurred those of track 1.5 diplomacy. As declared by interviewee ID12: "The Cabinet Office sometimes relies on Chatham House, particularly in case of crisis, as a place where some conversations can be facilitated". This is more explicitly the position of the Royal United Service Institute (RUSI) in London, relative to meetings with North Korea. According to its 2012-13 an nual report, "In November 2012, RUSI became one of the first Western think-tanks in history to carry out nuclear talks with the Korean People's Army in Pyongyang. RUSI also gained access into the unique insights of the Korean Worker's Party and the North Korean Ministry of Foreigh into the nuquer Affairs, all of whom offered dramatic perspectives of the security situation on the Korean peninsula. (...) RUSI has been asked to brief the UK Foreign and Commonwealth Office, as well as the US Special Representatives for North Korea and the Six-Party Talks, Ambassadors Glyn Davies and Clifford Hart." ID15 called all these activities 'cultural diplomacy'. According to ID17: "We can work in more informal settings. This can also mean being used by governments. They have realized that think tanks can be used as a channel for unofficial diplomacy." In sum, in this article, references to unofficial or track two diplomacy include all the activities that some think tanks may carry out, behind closed doors and without media attention, to support bilateral or multilateral meetings betwe Nowotny (2011, p. 242)

\begin{tabular}{lll}
\hline & & \\
\hline Indicators & Observed range of variation & Observed answers \\
\hline Overall & From the challenge of maintaining a & - Reputation \\
goals of the & good reputation to actively seeking & - Media visibility \\
organization & and obtaining access to decision & - Informing public opinion debate \\
& makers & - Informing decision makers' debate \\
& & - Seeking access to decision makers \\
& & - Obtaining constant access \\
\hline Number of & Occasions of contacts with the & - Every day \\
parliamentary & legislative may vary from very few/ & - Every week \\
hearings (in a & none during a year to everyday & - Every month \\
year) & access & - A few times during the year (5-10) \\
& & - Never/unknown \\
\hline
\end{tabular}

The empirical part of this research is based on a web survey ${ }^{17}$ used to approach the sample of think tanks listed in Table 3 and to start collecting preliminary data. The survey was first promoted by e-mail, and most contacts agreed to reply to the questions of the survey in person. A total of $17 \mathrm{semi}$ structured in-depth interviews were arranged by email or face to face with eleven organizations in two countries in 2013-14 (see Table 4 and Appendix). Informal conversations with other people in the sector together with information available on the websites of think tanks were also useful in refining the analysis. The aim of the face-to-face interviews was twofold: first, to directly observe the topic of interest and, second, to collect comparable data from these organizations. Close observation was possible whenever there was cooperation from the think tank itself and its researchers. To respect privacy and make a better conversation setting, most interviews were not recorded.

17 A free online survey was set up with Google Drive. The first section of the online survey contain general questions aimed at acquiring some more knowledge on the think tank's main activities as well as on the organization in general: staff, funding and products. The second section's objectives were to deepen the relationships of the interviewed organization with other policy actors, to assess the belonging to any network - being national or international - and finally to tors, to assess the beng to any netwily to ask to assess the belonging to any neww - bing niona analysis was used to identify the think tanks to include in the sample, using the opinions of their
peers. 
Table 3 Sample of investigated foreign policy think tanks in Italy and in the UK

\begin{tabular}{ll}
\hline Italy & Website \\
\hline Istituto Affari Internazionali (IAI), Rome & $\underline{\text { http://www.iai.it/ }}$ \\
\hline $\begin{array}{l}\text { Istituto per gli Studi di Politica Internazionale (ISPI), } \\
\text { Milan }\end{array}$ & $\underline{\text { http://www.ispionline.it// }}$ \\
\hline Aspen Institute Italia, Rome & $\underline{\text { https://www.aspeninstitute.it/ }}$ \\
\hline Centro Studi di Politica Internazionale (CESPI), Roma & http://www.cespi.it/ \\
\hline Centro Studi Internazionali (CESI), Roma & $\underline{\text { http://www.cesi-italia.org/ }}$ \\
\hline $\begin{array}{l}\text { Centro Italiano per la Pace in Medio Oriente } \\
\text { (CIPMO), Milan }\end{array}$ & $\underline{\text { http://www.cipmo.org/ }}$ \\
\hline United Kingdom & \\
\hline Chatham House (RIIA), London & $\underline{\text { http://www.chathamhouse.org.uk/ }}$ \\
\hline $\begin{array}{l}\text { Royal United Services Institute for Defence and } \\
\text { Security Studies (RUSI), London }\end{array}$ & $\underline{\text { http://www.rusi.org/ }}$ \\
\hline Centre for European Reform (CER), London & $\underline{\text { http://www.cer.org.uk/ }}$ \\
\hline European Council on Foreign Relations (ECFR), & $\underline{\text { http://www.ecfr.eu/ }}$ \\
London & $\underline{\text { http://www.iiss.org/ }}$ \\
\hline $\begin{array}{l}\text { International Institute for Strategic Studies (IISS), } \\
\text { London }{ }^{18}\end{array}$ & \\
\hline
\end{tabular}

Table 4 Interview types and IDs

\begin{tabular}{|c|c|c|c|}
\hline Country & ID & Think tank & Type of interview and place \\
\hline \multirow[t]{6}{*}{ Italy } & 1,2 & ISPI & Face-to-face, Milan \\
\hline & 3,4 & $|A|$ & Face-to-face, Paris, and email \\
\hline & 5 & ASPEN & Face-to-face, Rome \\
\hline & 6 & CESI & Email \\
\hline & 7 & CESPI & Email \\
\hline & 8,9 & CIPMO & Face-to-face, Milan \\
\hline \multirow[t]{4}{*}{ UK } & 10,11 & ECFR & Face-to-face, London and Tarragona ${ }^{19}$ \\
\hline & 12,13 & RIIA & Face-to-face, London \\
\hline & 14,15 & RUSI & Face-to-face, London \\
\hline & 16,17 & CER & Face-to-face, London \\
\hline
\end{tabular}

\section{SURVEY RESULTS AND DISCUSSION OF FINDINGS}

The results of the survey are summarized in the Table 5 and 6 . The data that are presented refer to the indicators that have been identified in the article. These results are then discussed to highlight commonalities and differences between the two cases and to compare them with the hypotheses made in the explanatory framework. The interview occurred at the margin of the 2014 EuroMeSCo Conferer (Spain) on 2-3 October 2014. EuroMeSCo is a network of think tanks on politics and security in the Mediterranean. 


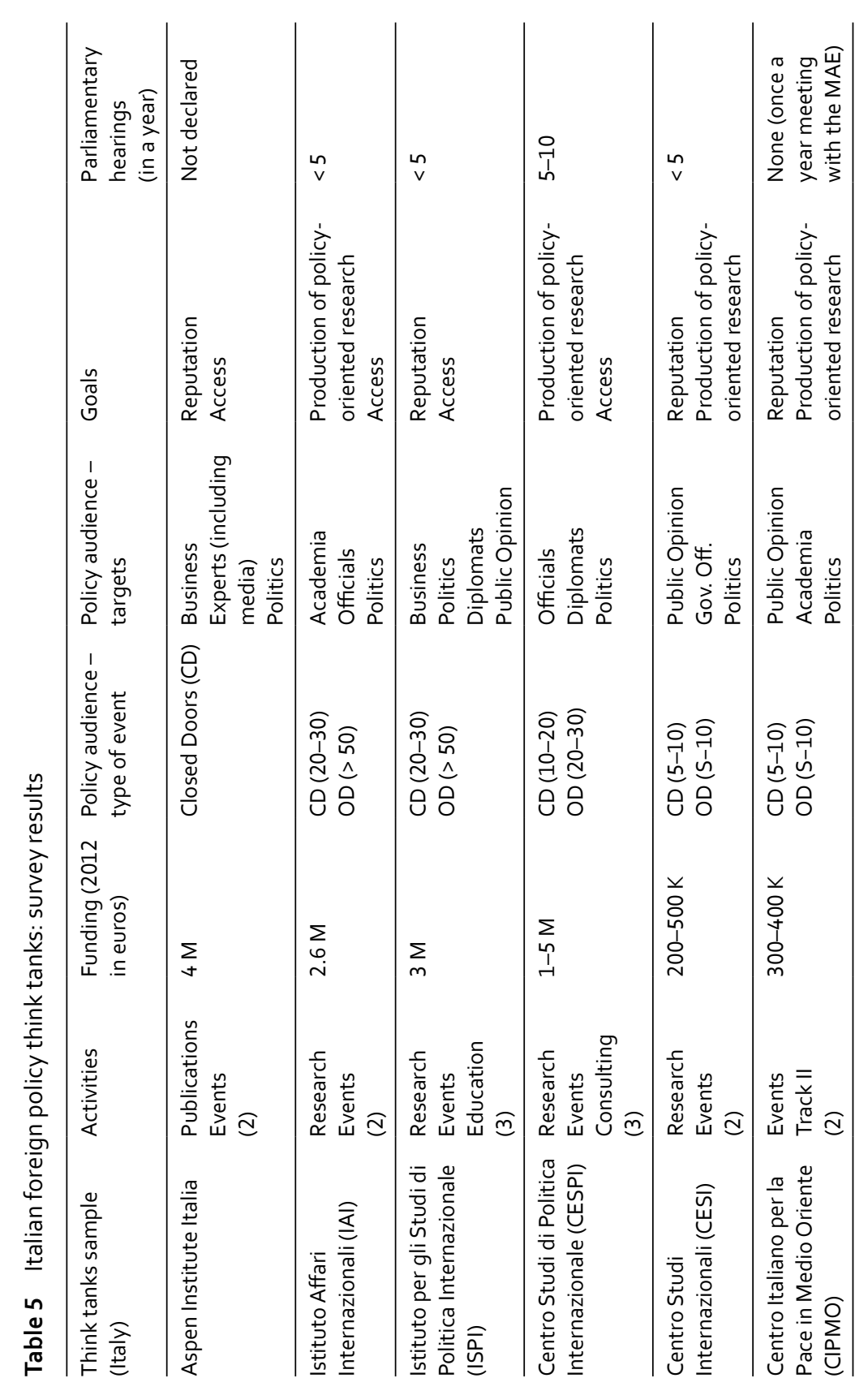

Table 6 British foreign policy think tanks: survey results

\begin{tabular}{|c|c|c|c|c|c|c|}
\hline $\begin{array}{l}\text { Think tanks } \\
\text { sample (UK) }\end{array}$ & Activities & $\begin{array}{l}\text { Funding } \\
\text { (2012 in } \\
\text { euros) }\end{array}$ & $\begin{array}{l}\text { Policy } \\
\text { audience - type } \\
\text { of event }\end{array}$ & $\begin{array}{l}\text { Policy } \\
\text { eaudience - } \\
\text { targets }\end{array}$ & Goals & $\begin{array}{l}\text { Parliamentary } \\
\text { hearings } \\
\text { (in a year) }\end{array}$ \\
\hline $\begin{array}{l}\text { Royal } \\
\text { Institute for } \\
\text { International } \\
\text { Affairs, } \\
\text { Chatham } \\
\text { House (RIIA) }\end{array}$ & $\begin{array}{l}\text { Research } \\
\text { Events } \\
\text { Track II } \\
\text { (3) }\end{array}$ & $12.7 \mathrm{M}$ & $\begin{array}{l}C D(>50) \\
\text { (events are } \\
\text { for members } \\
\text { only, but } \\
\text { membership is } \\
\text { broad) }\end{array}$ & $\begin{array}{l}\text { Public } \\
\text { Opinion } \\
\text { Diplomats } \\
\text { Business } \\
\text { Officials }\end{array}$ & $\begin{array}{l}\text { Reputation } \\
\text { Production } \\
\text { of policy- } \\
\text { oriented } \\
\text { research } \\
\text { Informing } \\
\text { the debate } \\
\text { Access }\end{array}$ & Unknown \\
\hline $\begin{array}{l}\text { Royal United } \\
\text { Services } \\
\text { Institute } \\
\text { for Defence } \\
\text { and Security } \\
\text { Studies } \\
\text { (RUSI) }\end{array}$ & $\begin{array}{l}\text { Research } \\
\text { Events } \\
\text { Education } \\
\text { Consulting } \\
\text { Track } 1.5 \\
\text { and } \\
\text { Track II (5) }\end{array}$ & $4.5 \mathrm{M}$ & $\begin{array}{l}C D(20-30) \\
\text { OD }(20-30)\end{array}$ & $\begin{array}{l}\text { Public } \\
\text { Opinion } \\
\text { Businesses } \\
\text { (Military } \\
\text { industry etc.) } \\
\text { Media } \\
\text { Diplomats } \\
\text { Armed } \\
\text { Forces } \\
\text { Other TT }\end{array}$ & $\begin{array}{l}\text { Visibility } \\
\text { Informing } \\
\text { policy- } \\
\text { makers' } \\
\text { debate }\end{array}$ & About $35-50$ \\
\hline $\begin{array}{l}\text { Centre for } \\
\text { European } \\
\text { Reform } \\
\text { (CER) }\end{array}$ & $\begin{array}{l}\text { Research } \\
\text { Events } \\
\text { Lobbying } \\
\text { (CER is not } \\
\text { registered } \\
\text { as a } \\
\text { charity) } \\
\text { (3) }\end{array}$ & $1.6 \mathrm{M}$ & Only CD & Politics & $\begin{array}{l}\text { Production } \\
\text { of policy- } \\
\text { oriented } \\
\text { research } \\
\text { Access }\end{array}$ & Every day \\
\hline $\begin{array}{l}\text { European } \\
\text { Council on } \\
\text { Foreign } \\
\text { Relations } \\
\text { (ECFR) }\end{array}$ & $\begin{array}{l}\text { Research } \\
\text { Events } \\
\text { Advocacy } \\
\text { Track Two } \\
\text { (4) }\end{array}$ & $5.5 \mathrm{M}$ & $\begin{array}{l}\text { CD (100) } \\
\text { OD (100) }\end{array}$ & $\begin{array}{l}\text { Politics } \\
\text { Diplomats } \\
\text { Officials } \\
\text { Journalists } \\
\text { Third sector } \\
\text { Other TT } \\
\end{array}$ & $\begin{array}{l}\text { Visibility } \\
\text { Production } \\
\text { of policy- } \\
\text { oriented } \\
\text { research } \\
\text { Access }\end{array}$ & About 12 \\
\hline $\begin{array}{l}\text { International } \\
\text { Institute for } \\
\text { Strategic } \\
\text { Studies (IISS) }\end{array}$ & $\begin{array}{l}\text { Research } \\
\text { Events } \\
\text { Consulting } \\
\text { (3) }\end{array}$ & $16.5 \mathrm{M}$ & $\begin{array}{l}C D \text { (unknown) } \\
\mathrm{OD}(>50)\end{array}$ & $\begin{array}{l}\text { Business } \\
\text { Diplomats } \\
\text { Officials }\end{array}$ & $\begin{array}{l}\text { Promoting } \\
\text { sound } \\
\text { policies } \\
\text { Access }\end{array}$ & Unknown \\
\hline
\end{tabular}

Notes to Tables 5 and 6 :

1. The category of politics may include government officials but it is more general. It refers more broadly to politicians, even those that have no government office. 
2. $C D$ : closed-doors events are not publicly accessible; $O D$ : open-doors events are those where the public needs only register in order to participat

3. CER did not deny, and ECFR declared, that lobbying and advocacy are part of their activities.

The main differences between the two cases that emerge from the results of the survey relate to funding, parliamentary hearings, events and types of ac tivity carried out. Going back to the first hypothesis that has been made in this research, we have identified the following principal features of the two political contexts that can help explain why the cooperation between think tanks and policymakers varies in the countries analysed. One of the main systemic incentives identified is connected to the available amount of funding that cir culates in a political system ${ }^{20}$. Specifically, the results of this survey only allow for comment on the amount of money that may influence the relationship between think tanks and policymakers (in Italy and in the UK), and, as a consequence, influence the production of policy knowledge within that system. For instance, budgets of Washington foreign policy think tanks such as the Brookings Institution or the Carnegie Endowment for International Peace (around 100 million dollars) are extremely high relative to their European counterparts. Nonetheless, keeping these amounts in mind, there are differences even within European countries, which differences emerge by looking at the annual budgets of think tanks in Italy and in the UK: the highest budget for a think tank is 4 million euros in Italy, compared to 16.5 million in the British case. Thus, the amount of 'political money', that is money invested in the decision-making process, is probably higher in the UK than in Italy. Also, in the UK most of this money is raised among private and corporate donors. In Italy, with the exception of the Aspen Institute, where 95\% of members are private individuals, think tanks have benefitted from public contributions directly or indirectly. Specifically, for instance, the IAI and the ISPI received a contribution of 92,000 euros from the Ministry of Foreign Affairs in the year 2012 (these data were available on the Ministry website in early 2014 but the link has now disappeared) because they are listed as so-called "Enti Internazionalistici" (eligible for benefits under Law No. 948/1982). As an indirect support, most Italian

20 For instance, it is worth considering that the role of money in politics is profoundly divergen in Europe and in the U.S. According to a recent article that appeared in the Washington Post a budget of 889 million dollars would be dedicated to the 2016 U.S. elections by businessmen Charles and David Koch, financing not only politically active groups, but also think tanks, foundations and universities. See http-/WwW washingtivpostcom/politicskoch-backed(1) a06b-9df2002b86a0 story.html (accessed 27 January 2015). think tanks are based in publicly owned buildings in the centres of Rome or Milan $^{21}$.

Another feature that can be derived from the data collected relates to the willingness of policymakers to turn to think tanks for expertise. It is extremely difficult to quantify contacts between policymakers and think tanks because they are generally observable rather qualitatively. To understand the relations of think tanks with the legislative branch, this research uses the indicators of the number of invitations to parliamentary hearings and of events held in parliamentary offices. According to the data collected, British think tanks seem much more active than the Italian ones. While the latter declare only very limited to no participation (fewer than five hearings every year) the former have at least one hearing a month (ECFR), almost one every week (RUSI) or even one every day (CER). With the exception of the ISPI and the IAI, think tanks in the UK organize events more frequently, including closeddoors events.

Other peculiar differences that emerge between the two contexts analysed relate to the activities carried out, and especially that of unofficial diplomacy. According to the data, it seems that only the CIPMO was involved in this activity in Italy ${ }^{22}$. However, its dimension both in terms of staff and budget is barely comparable to the better-established institutes in London (e.g., the IISS, the RUSI and the Chatham House). As for activities, it needs to be underlined that the CER is involved in lobbying and the ECFR in advocacy. Finally, a more blurred indicator is discussed, namely that of think tanks' goals. In this analysis what emerges is that think tanks tend to share similar goals, although described in different terms. While not everyone decides to seek access to decision makers ${ }^{23}$, only a few are probably able to obtain constant access (CER certainly seems to be capable of pursuing that goal). Reputation is also the more frequent answer among Italian think tanks, together with 'producing policy-oriented research'. In general, then, not everyone seeks media visibility, and whether or not they declare it, most share the general purpose of informing the debate in the sphere of international affairs using different channels of communication, including the media system.

21 This has been verified for ISPI, IAI, Aspen and CESPI.

22 Especially in the past, CIPMO was active in the organization of meetings behind closed doors for both officials and civil society representatives to cope with the Israeli-Palestinian conflict.

23 For instance, CESI and CIPMO do not seek access, even if they claim politics to be among their Fargets. RUSI does not seek access but it aims at informing policymakers' debate, for example through civil sevants at the UK Ministry of Defence. If an organization can be heard at the Minthe it probably has access to policymakers. 
To conclude, a practical exercise can now be attempted. Based on the results derived from field work, the think tanks surveyed in both countries will be positioned in the typology proposed in the first part of this study, so as to test the second hypothesis (think tanks pursue different strategies of action relative to policymakers).

Table 7 Empirical results shown in the proposed typology

\begin{tabular}{lll}
\hline Audience & Restricted & Broad \\
$\begin{array}{l}\text { Type of engagement } \\
\text { with policymakers }\end{array}$ & & \\
\hline Active & $\begin{array}{l}\text { The lobbyist } \\
\text { (CER, UK; } \\
\end{array}$ & The advocate \\
& ASPEN, Italy) & (RIIA, ECFR, IISS, RUSI, UK) \\
\hline Passive & Irrelevant & The generalist \\
& (CIPMO, CESI, Italy) & (CESPI, ISPI, IAI, Italy) \\
\hline
\end{tabular}

According to the data collected, the Centre for European Reform (CER) and the Aspen Institute Italy are both sponsored by private donors (mainly businesses) and their main interlocutors can be found in the world of politics and business (especially for Aspen). They operate only behind closed doors and they seek access as a goal. Their strategy is the most similar to that of the lobbyist type. Similarly to Aspen, the Chatham House (RIIA) is based on broader membership: corporate donors may become members as well as students ${ }^{24}$ whereas events are only closed-doors. Access is part of the think tank's business, but the audience it refers to is broader than simply policymakers, ranging from businesses and officials to diplomats, experts and students. Similarly, its goals are broader: "maintaining the institute's reputation over the years", as declared in an interview with ID12, and "to advance the sciences of international politics, economics, and jurisprudence, and the study, classification and development of the literature of these subjects", as stated in clause 4 of its Royal Charter. Similarly, the ECFR, the IISS and the RUSI all seek active engagement with domestic policymakers, but also with an international perspective. All of them reach an audience that includes different types of actors. Specifically, they promote policy ideas in the fields of foreign policy and international affairs (not just European affairs, even in the case of the ECFR) among defined

24 Student membership costs $f 125$. See: http://www.chathamhouse.org/become-member (accessed 7 February 2015). target audiences, of which policymakers are an important but not the sole component. The main difference marking out those think tanks whose strategy has been named 'generalist' in this exercise (the ISPI, the IAI and the CESPI) is that their attempts to engage with politics are much weaker. Research, consulting and education represent the core of their activities, are seldom directed towards politics, and are aimed at raising funds for the subsistence of the organization. Lastly, in comparison with other think tanks in the sample, two organizations (CIPMO, CESI) are less relevant in terms both of their capacity to reach a broad audience and their capacity to engage significantly with policymakers. Also, neither their staff nor their funding are sufficient to allow them to be competitive.

Finally, following the proposed model of analysis and given the observed differences, the comparison between the two political systems of context shows that each has stimulated the development of different types of think tanks. Active engagement with policymakers is prevalent among London-based think tanks, particularly given the higher numbers of parliamentary hearings and of closed-doors events carried out. As a consequence, advocacy-related activities are central. Differently from the Italian scene, then, all foreign policy think tanks are concentrated in the capital, close to the Parliament and the Ministries. The demand for foreign policy expertise from decision makers is higher. Weaker demand, instead, prevails in the Italian case, so that interactions that involve cooperation with policymakers are less frequent. As a consequence, impact on the formulation of policy issues is much more unlikely.

\section{CONCLUSIONS}

Nowadays, a 'think tank' has become a global label for a broad range of organizations. This article has focused on one set of these organizations in the policy community: those involved in the fields of foreign policy and international af fairs. Within this community, the organizations investigated have two main features in common: first, they rely on expertise; and second, they engage with their external environment, and more specifically, seek co-operation with policymakers. Indeed, the hypothesis verified in this piece of research is that the demand for expertise from policymakers is an extremely important component in understanding differences in the ways think tanks have institutionalized into different political systems in Europe. Starting with the assumption that think tanks have been imported from the United States, these political contexts have set incentives for different degrees of co-operation between think tanks and policymakers. For instance, the more money is available in the system, the 
better able think tanks are to raise money, to establish a solid reputation, and to become a reference point for the media and for the policy community as a whole. In all, it is shown that there is a public dimension of foreign policy that is able to emerge not only from governments but also from these kinds of ac tors, or even from the governments' use of these actors (as in the case of unofficial diplomacy). Furthermore, more willingness from the demand side of policy expertise to consult think tanks, either for advice or simply for policy validation, is indicated by the higher number of closed-door events and parliamentary hearings in which these organizations are involved. On the contrary, when access is difficult, either because the think tank's reputation is not established or because policymakers scarcely rely on external expertise (as seems more evident in the case of Italy), the think tanks tend to shift to other, more accessible, core audiences (the public opinion, the academia or businesses), and advocacy becomes a far less important activity for them. There is no poin of devoting a great effort in promoting new policy ideas if the demand is weak and the 'market' is little competitive. Finally, the way the explanatory framework is constructed in the article reverses the classical question regarding the influence of think tanks over officials, focusing on to what extent the European political contexts have influenced think tanks' strategies and overall institutionalization, rather than how think tanks have influenced their political environments.

Although the main differences between the case studies have been highlighted, empirical testing of the hypotheses proposed in the article would require a broader comparative research design. Drawing on the suggested explanatory framework, further research might cover more cases and other actors that are part of the audience of think tanks (such as the military industry) or examine in depth the process of negotiation on specific issues in which some of the think tanks in the sample are involved (such as unofficial diplomacy).

\section{Appendix: The challenges of surveying think tanks}

It is not an easy task to survey think tanks and ask details about their organ ization, or to survey elites in general (Nownes, 2006, pp. 225-231). Severa reasons for this can be identified. First, think tank members are generally unwilling to talk about their organizations. Although some of them seek visibility, they are not used to being under scrutiny. In addition, there are differen interests and ideas to protect, because think tanks themselves serve as informal platforms for unofficial talks between different policy actors, often behind closed doors or in the context of invitation-only events. Second, think tanks in Europe are generally understaffed in comparison to some of their counterparts in Washington, DC. Practically, this translates into their having few or no employees devoted to external communication, and when they do they do not always charge them with responding to questions about the organization itself. Consequently, researchers are more exposed to external communication and media enquiries. They are more easily accessible; do not always share the same goals as the institution; can be affiliated with different institutions at the same time (for instance, the academia); and focus on a specific area of expertise. In contrast, directors of think tanks or heads of programs are more difficult to approach. If available for interviews, they tend to offer more standardized answers, which are usually already available in the annual report; they are more inclined to oversell the organization, compared to younger researchers; and often they are unwilling to answer questions they find too sensitive. In sum, interviewing researchers is a good compromise, helping us gain insight into the organization's routine and avoid hearing only one part of the story. Openness and willingness to talk have been found among researchers in the U.S. context.

\section{Acknowledgements}

I would like to express my gratitude to the Department of Politics and International Relations at the Royal Holloway University of London for their assistance and support in the period of my visiting in London in spring 2014, and especially to Professor Ben O'Louglin who co-supervised my work while there. I am also grateful to Professor Giliberto Capano and to all the other discussants of the panel on 'Making policies from abroad: external actors and national polcymakers in contemporary Europe' at the 2014 Annual Conference of the Italian Society of Political Science (SISP) for their comments on an earlier version of this paper. I also thank the two CEJPP anonymous reviewers and the journal editors for their constructive remarks. The responsibility for the results of this work, and for any mistakes, is mine alone.

\section{REFERENCES}

Abelson, D. E. (2013). Think Tanks and U.S. Military and Diplomatic Affairs, in The

Oxford Encyclopedia of American Military and Diplomatic History, Oxford University Press, Online version available at: http://www.oxfordreference.com/view/10.1093/ acref/9780199759255.001.0001/acref-9780199759255-e-510 (accessed 30 January 2015)

Abelson, D. E. (2002). Think tanks and U.S. foreign policy: an historical view, US Foreign Policy Agenda: An Electronic Journal of the U.S. Department of State, 7 (3). 
Abelson, D. E. (2006). Capitol Idea:Think Tanks and U.S. Foreign Policy, McGill-Queen's University Press.

Abelson, D. E. (2007),.Any Ideas? Think Tanks and Policy Analysis in Canada, in Dobuzinskis L., Laycock D. H., Howlett M. (ed.), Policy Analysis in Canada: The State of the Art, Toronto: University of Toronto Press, 551-573.

Abelson, D. E. (2014). Old world, new world: the evolution and influence of foreign affairs think tanks. International Affairs, 90 (1), 125-142.

Béland, D., (2009). Ideas, institutions, and policy change. Journal of European Public Policy, $16(5), 701-718$.

Béland, D. \& Cox, R.H. (eds., 2011). Ideas and Politics in Social Science Research, Oxford University Press.

Bertelli, M. \& Wenger, J. B., (2009). Demanding Information: Think Tanks and the US Congress. British Journal of Political Science, 39 (2), 225-242.

Bevir, M., Daddow, O., \& Hall, I. (2013). Introduction: Interpreting British Foreign Policy, The British Journal of Politics \& International Relations, 15 (2), 163-174.

Boucher, S. (2004). Europe and its think tanks: A promise to be fulfilled. An analysis of think tanks specialised in European policy issues in the enlarged European Union. Notre Europe Studies and Research n. 35.

Capano, G. (2009). Understanding Policy Change as an Epistemological and Theoretical Problem, Journal of Comparative Policy Analysis: Research and Practice, 11, 7-31.

Denham, A. (1998), .British Think-Tanks And The Climate Of Opinion, London: Routledge.

Diletti, M. (2009). I think tank. Le fabbriche delle idee in America e in Europa, Bologna: II Mulino.

Diletti, M. (2011). I think tank al confine tra conoscenza, valori e interessi. II caso italiano, Rivista Italiana di Politiche Pubbliche, 2, pp. 345-376.

Gaskarth, J. (2013). British Foreign Policy: Crises, Conflicts and Future Challenges, Polity Press.

Gerring, J., (2007). Case Study Research: Principles and Practices, Cambridge University Press.

Gilroy, P. (2012). Have Think Tanks in Washington D.C. Become Politicized?, The Hertie School Student Paper Series, 1.

Héritier, A. (2002).New Modes of Governance in Europe: Policy Making without Legislating?, in Héritier A. (eds.) Common Goods: Reinventing European Integration Governance, Rowman \& Littlefield Publishers, 185-206.

Higgott, R. \& Stone, D. The limits of influence: foreign policy think tanks in Britain and the USA. Review of International Studies, 20 (1), 1994.

Hofmeister, H. \& Breitenstein, A. P. (2008). Contemporary Processes of Transnationalization and Globalization, International Sociology, 23, 480-487.

loannides I. \& Missiroli A. (2012). European Think Tanks and The Eu. Berlaymont PaperBureau of European Policy Advisers (BEPA), European Commision, Issue 2.

Jacobs, L. R., \& Page, B. I., (2005). Who Influences U.S. Foreign Policy?. American Political Science Review, 99 (1), 107-123.

Kriesi, H., Adam, S., \& Jochum, M. (2006). Comparative analysis of policy networks in Western Europe. Journal of European Public Policy, 13 (3), 341-361.

Longhini, A (2015). Foreign policy think tanks in the Italian political context: evolutions and perspectives, International Journal: Canada's Journal of Global Policy, 70 (4).
Lentner, H. H. (2006). Public Policy and Foreign Policy: Divergences, Intersections, Exchange, Review of Policy Research, 23 (1), 169-181.

Lindblom, C. E. \& Cohen, D., (1979). Usable Knowledge, New Haven, Conn.: Yale University Press.

Lindquist, E. (2000). Think tanks and the ecology of policy inquiry, in Stone, D., Banking on Knowledge: The Genesis of the Global Development Network, London: Routledge, 223-239.

Lipset, S. M. (1996). American Exceptionalism: A Double-Edged Sword, New York:W.W. Norton\&Co. Inc.

Mapendere, J.(2005). Track One and a Half Diplomacy and the Complementarity of Tracks, Culture of Peace Online Journal, 2:1, 66-81.

Medina, I., \& Guttormsen, D., (2013). "Visibility and Activity: Foreign Affairs Think Tanks in the United Kingdom", Political Perspectives, 2013, 7:1, 46-74.

Medvetz, T. (2012). Think tanks in America, Chicago: University of Chicago Press.

McGann, J. G. (2012). "The Global Go-To Think Tanks Report 2011. The Leading Public Policy Research Organizations in the World", The Think Tanks and Civil Societies Program, web paper.

Montville, J. (2006). Track Two Diplomacy: The Work of Healing History. The Whitehead Journal of Diplomacy and International Relations, 15-25.

Nownes, A. (2007). Total Lobbying. What Lobbyists Want And How They Try Get It, Cambridge: Cambridge University Press.

Nowotny, H. (1990). In Search of Usable Knowledge: Utilization Contexts and the Application of Knowledge, Frankfurt-Boulder, Westview Press-Campus Verlag.

Nowotny, T. (2011). Diplomacy and global governance: The diplomatic service in an age of worldwide interdependence. New Brunswick, NJ: Transaction.

Putnam, R. D. (1988). Diplomacy and domestic politics: the logic of two-level games. International Organization, 42 (3), 427-460.

Radaelli, C. and Lucarelli, S.(2004). Italy: Think Tanks and the Political System, in D. Stone, A. Denham and M.

Radin, B. A. (2014). Knowledge Actors and Transnational Governance: The Private-Public Policy Nexus in the Global Agora. Journal of Comparative Policy Analysis: Research and Practice, 16 (1), 113-115.

Sabatier, P. A. \& Jenkins-Smith, H. C. (1993). Policy Change and Learning. An Advocacy Coalition Approach, Boulder: Westview Press.

Sanders, K. (2008). Communicating politics in the twenty-first century, Palgrave Macmillan

Schmitter, P. C. (2008). The Design of Social \& Political Research, in della Porta D. \& Keating M., Approaches and Methodologies in the Social Sciences: A Pluralist Perspective, 263-295.

Stone, D. \& Denham, A., (1996). Capturing the Political Imagination. Think Tank and the Policy Process, London: Frank Cass.

Stone, D. \& Denham, A., (2004). (eds.), Think Tank Traditions: Policy Research and the Politics of Ideas, Manchester: Manchester University Press.

Tilly, C., \& Tarrow, S., (2007). Contentious politics. Boulder, Colo.: Paradigm.

VV. AA., (2014). Ottant'anni di politica internazionale a Milano e in Italia (1934-2014), Archivio ISPI. 
Walston, J. (2007). Italian Foreign Policy in the 'Second Republic'. Changes of Form and Substance, Modern Italy, 12 (1), 91-104

Wallace, W. (1994). Between two worlds. Think-tanks and foreign policy, in Hill C. et al. Two Worlds of International Relations: Academics, Practitioners and the Trade in Ideas, London: Routledge.

Weaver, R. K. (1989). The changing world of think tanks, PS: Political Science and Politics 22 (2), 563-578.

Weiss, C. H. (1982). Policy Research in the Context of Diffuse Decision Making. The Journal of Higher Education, 53 (6).

Wiarda, H. J. (2010). Think Tanks and Foreign Policy: The Foreign Policy Research Institute and Presidential Politics, Lexington Books. 